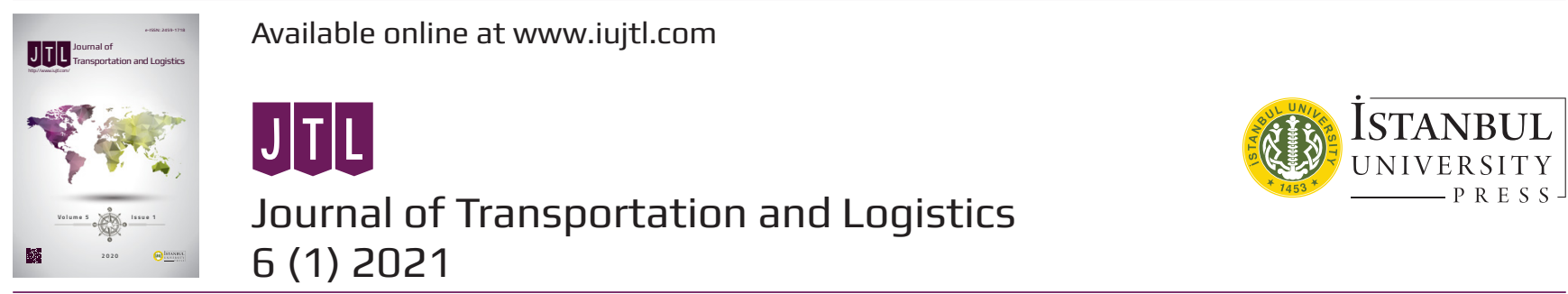

\title{
Evaluation of the Possible Use of the Ankara-Sivas High-Speed Railway Line for Freight Transport
}

\author{
Hülya Zeybek ${ }^{1}$
}

\begin{abstract}
Logistics trends and the growing awareness of more sustainable transport in the global market have been a strong impetus for the growth of rail freight transport, particularly evident in the transport of time-sensitive, high-value, and capital-intensive goods. Therefore, expanded High-Speed Railway (HSR) systems provide a reliable opportunity for fast freight transport. In Turkey, the length of the HSR has reached 1,213 km and 1,889 $\mathrm{km}$ more are under construction, mostly dedicated to passenger transport. This research investigates the possible use of the new Ankara-Sivas HSR line for freight by analyzing the future traffic potential to find out the spare capacity for freight traffic. The results of the research reveal that the traffic potential on the Ankara-Sivas HSR line might not be justified by passenger traffic alone and the spare capacity should be used by express freight trains. Considering that Turkey is well prepared to become a Eurasian transport hub connecting Europe with Asia via the Middle Corridor, the outcome of this research may contribute to the development of suitable solutions that may improve the economic, environmental, and social sustainability of HSR systems.

Keywords: High-speed railways, Freight transport, Ankara-Sivas HSR, Middle Corridor, Trade
\end{abstract}

1 Sorumlu yazar/Corresponding author: Hülya Zeybek (Dr), Eskişehir Teknik Üniversitesi, Ulaştırma Meslek Yüksek Okulu, Eskişehir, Türkiye E-mail: hulyazeybek@eskisehir.edu.tr ORCID: 0000-0002-4671-5330 


\section{Introduction}

In Turkey, expenditure on rail infrastructure increased significantly between 2003 and 2019. Within this 16-year period, USD 26.6 billion have been invested in rail infrastructure, mostly for passenger transport. For instance, in 2020, almost half of the planned rail investments are projected to be spent on HSR and SR (speed-rail), in which the AnkaraSivas HSR line takes the biggest share, as in the previous year (UAB,2020). HSR has the ability to move goods in a more efficient, safe, and cost-effective way, which can improve trade links in Europe and Asia (Pazour et al. 2010). Although the majority of HSR lines around the world are dedicated to passenger traffic, in a number of countries freight services are operated on HSR (Watson et al., 2018). Without a doubt, HSR is a technological advance and a symbol of modernity. However, there are questions regarding its economic, social, and environmental impacts, which are enormously restrictive, as argued by Albalate and Bel (2012). Despite that, the growth of e-commerce and the development of digital technologies have increased the demand for fast delivery, requiring time-sensitive, reliable services. Currently, most of these goods are transported by road or air. However, all of these could be an opportunity for HSR freight services.

In general, high-speed lines are suitable where there are densely populated centers located between 100 and 1,000 km apart, especially between 200 and $600 \mathrm{~km}$ apart (UNECE, 2017). Cars at short distances and planes at longer distances are more competitive than HSR. Although HSR was first designed only for passenger transport, in the 1990s, some countries attempted to use high-speed rail networks for express freight services to yield economic benefits (Gao et al., 2017).

There are four different operational models for high-speed rail systems: 1) The exclusive exploitation model (Japanese Shinkansen): a complete separation between high-speed and conventional services, each with its own infrastructure; 2) Mixed high-speed model (the French TGV): high-speed trains run either on specifically built new lines or upgraded segments of conventional lines; 3) The mixed conventional model (Spain-AVE): some conventional trains run on high-speed lines; and 4) Fully mixed model allowing both high-speed and conventional services to run (at their corresponding speeds) on each type of infrastructure (Germany-ICE), where high-speed trains occasionally use upgraded conventional lines, and freight services use the spare capacity of high-speed lines during the night (de Rus et al., 2009).

High-speed rail infrastructure is an expensive investment. The cost of a line increases proportionally with the design speed, and infrastructure capable of handling very highspeed operations ( $300 \mathrm{~km} / \mathrm{h}$ or more) is particularly costly (European Court of Auditors, 2018). Currently, many HSR lines have trouble covering construction costs with passenger revenues only, except for busy corridors such as Tokyo-Osaka or Paris-Lyon. Recovery of construction costs of HSR systems can be possible only through intensive use of their infrastructure. According to Amos et al. (2010), in a developing country with sufficient purchasing power, at least 20 million passengers per year must be expected to meet only the working expenses and interest costs of providing this capacity with high-speed service. If the market potential is not big enough to justify dedicated passenger use, 
HSR could be designed for mixed traffic: freight and passenger operations. That is, the incremental cost of the construction of a high-speed rail system can only be recovered with the intensive use of the line.

In literature, there are few studies on freight transport using HSR. Troche (2005) analysed methods of coordinating passenger and freight transport on high-speed rail. In their study, Watson et al. (2018) considered the future trends and possibilities of shifting freight from roads to HSR lines and studied the operational and technological constraints concerning freight traffic and the corresponding capabilities of HSR. Pazour et al. (2010) proposed a model to design a national high-speed rail network for freight distribution. Some scholars focused on express freight transport by high-speed rail in China (Gao et al., 2017). Ertem and Özcan (2016) presented a mathematical model for adding freight trains on HSR systems in Turkey and tested the model's applicability on the Ankara-Eskişehir, AnkaraKonya, Ankara-Sivas, and Eskişehir-Istanbul lines, considering various scenarios. They concluded that using HSR for freight transport increases the capacity of railway systems substantially. However, there is no study on a specific HSR project. In this study, we focus on a specific HSR project in Turkey and evaluate the possible use of the Ankara-Sivas High-Speed Railway line for freight transport by analysing the future traffic potential to find out the spare capacity for freight traffic.

\section{HSR in the World and Turkey}

After the birth of the high-speed rail system in the world in Japan in 1964 (Shinkansen at $210 \mathrm{~km} / \mathrm{h}$ ), the first European high-speed train (TGV) launched in 1981 in France at 260 $\mathrm{km} /$ hour (UIC, 2020a). In Turkey, the first HSR train started operations between Ankara and Eskişehir in 2009. Ankara-Konya HSR launched in 2011 and, finally, EskişehirIstanbul HSR was put in service in 2014. They are all dedicated to passenger transport and 8.1 million passengers in total were transported by HSR in 2018 (UAB, 2020).

Regarding HSR freight services, trains running from Europe to London use HS1 through the Channel Tunnel Rail Link for freight transport. Sweden has high-speed freight trains delivering post regularly. In France, TGV passenger trains were converted to transport express freight on the North and South railway network. In Germany and France, the freight trains on HSR operate during the night with a fixed schedule. Currently, approximately $5 \%$ of express cargo is transported by HSR in China (Watson et al., 2018). China started developing freight HSR, which will deliver high-value freight, such as e-commerce parcels. With the rise of e-commerce between Europe and China, Russian Railways (RZD) is working to develop a concept for a high-speed freight train between Moscow and Kazan $(700 \mathrm{~km}$ ) that can achieve 2-3 days transit time across Russia (Railway Technology, 2018). In Europe, with the Euro-Carex project, major European freight airports (Liège, Paris, Frankfurt, Koln, Amsterdam, Brussels, and London) are connected to carry air containers using the existing HSR network (Strale, 2016). In the USA, Amtrak offers freight express services by using HSR trains to carry freight and post (Watson et al., 2018).

Express freight services can be operated on HSR lines in two ways, either integrated 
with high-speed passenger trains or using special high-speed freight trains (Watson et al., 2018). Newly designed HSR freight trains are based on passenger rolling stock and organized as passenger trains. This operation eliminates the line capacity problem since freight multiple units (EMU's) can travel at the same speed as passenger trains. This will help improve the train utilisation rate.

This paper investigates the possible use of the new Ankara-Sivas HSR line for freight by analysing the traffic potential.

\section{The Importance of the Ankara-Sivas HSR Line for Freight Transport on the Middle Corridor}

The Turkish economy relies on an export-oriented development model, and brings imports from other countries that require high logistics performance in terms of speed, reliability, and connectivity (11th Development Plan of Turkey 2019-2023). In recent years, one significant characteristic of the Turkish economy is the increase in e-commerce. E-commerce is becoming an important export channel, as mentioned in Turkey's e-Export Strategy and Action Plan (2018-2020). The growing demand for e-commerce and express delivery services increases the opportunity for HSR to take part in the supply chain.

As an extention of the Baku-Tbilisi-Kars (BTK) Railway line and a section of the KarsEdirne transit route, the construction of Ankara-Sivas High-Speed Rail (Figure 1) is an important mega project on the Middle Corridor connecting Asian countries to Europe via Turkey, with costs estimated over USD 1 billion. The Ankara-Sivas HSR project was designed for $250 \mathrm{~km} / \mathrm{h}$ speed. The project includes 49 tunnels, totaling some 66 kilometers in length, with the longest being around 5.12 kilometers long. It will also have 53 viaducts totaling 27.5 kilometers in length. The line will also include 611 bridges and culvert structures and 217 overpasses and underpasses.

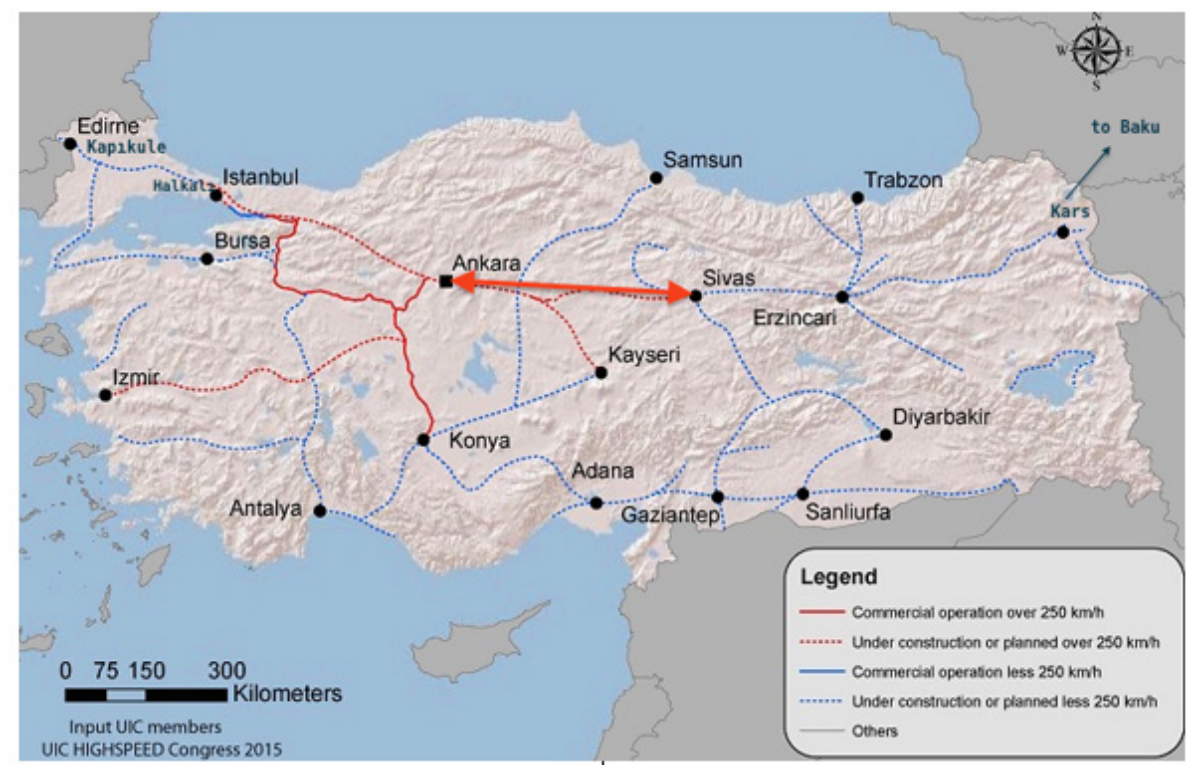

Figure 1. HSR Map of Turkey and the Ankara-Sivas HSR line

Source: Adapted from UIC, 2020b.High-Speed Database and Maps, https://uic.org/ passenger/highspeed/article/high-speed-database-maps 
The Ankara-Sivas HSR line is projected to be used as a passenger route. The population of Ankara is around 5.6 million, and Sivas has 600,000 people. This dedicated line could be quite expensive and unjustifiable on a cost-benefit basis, thus making mixed solutions a more viable option. If it is used as a cargo route as well, it can increase convenience and decrease the transit time of freight transport. Within this context, we will evaluate the importance of the Ankara-Sivas HSR Line for freight traffic from various aspects.

\section{The Ankara-Sivas HSR Line is on the Eurasian Middle Corridor}

The Middle Corridor is a multimodal corridor that aims to provide an alternative to the Eurasian northern routes and provides a strategic diversification away from reliance on Russia (Calabrese, 2019). It was launched in late 2013 to connect east and west, envisaging the revival of the ancient Silk Road.

This route starts from the Chinese port of Lianyungang and passes through Kazakhstan, the Caspian Sea, Azerbaijan, Georgia, and Turkey via the Baku-Tbilisi-Kars (BTK) railway extending further to Europe (Figure 2).

The Middle Corridor has gained a significant competitive advantage in terms of transport time and transport cost after the commissioning of the Baku-Tbilisi-Kars (BTK) railway line in 2017 and the opening of the Marmaray Bosphorus Tube Crossing to freight trains in 2019. There is an opportunity for the transport of high-tech electronic products such as laptops, hard disks, and semi-finished TV panels; textile products; auto parts; food and pharmaceutical products; and semi-finished and finished vehicles that require fast transport (Nikkei Asian Review, 2019). E-commerce transport could be a new market for this route. Thus, as an extension of the BTK Railway line, Ankara-Sivas HSR can contribute much to the competitiveness of the Middle Corridor.

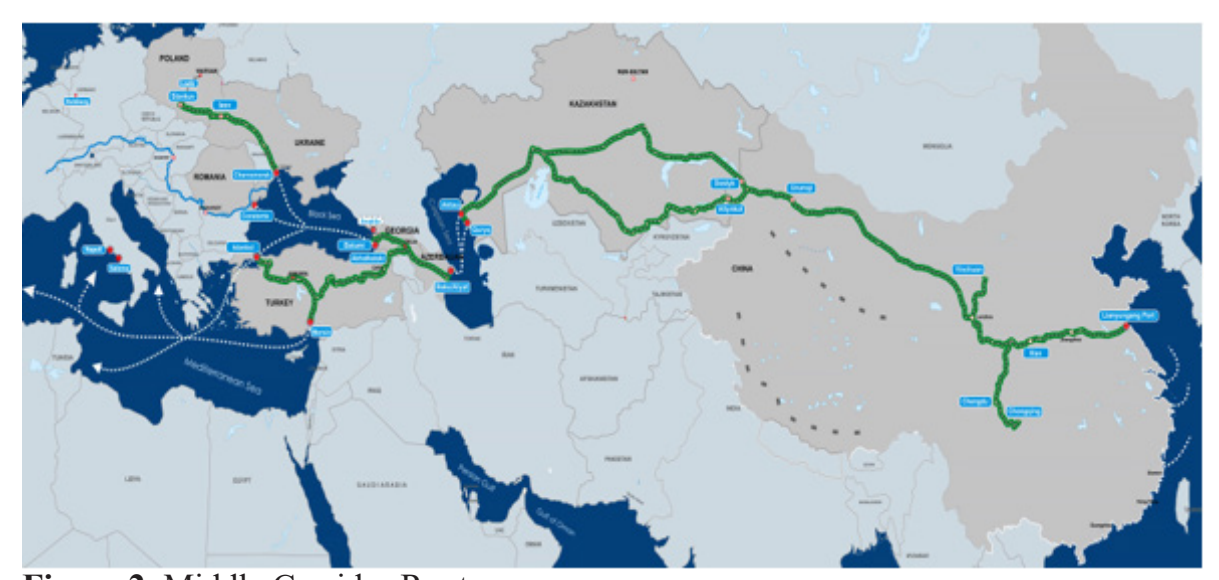

Figure 2. Middle Corridor Route

Source: Middle Corridor (2020) https://middlecorridor.com/en/route

2. Significantly shortens the existing rail route; provides a direct link between Ankara and Sivas.

The current Ankara-Sivas railway is $603 \mathrm{~km}$ connecting the two cities via Kayseri, and the travel time is 12 hours (UAB, 2019). The Ankara-Sivas HSR line (Figure 1) will shorten the existing railway by $198 \mathrm{~km}$, and traveling will take just two hours. Ankara- 
Sivas HSR is an important section of the Kars-Edirne transit railway line connecting to the BTK line. However, as only passenger trains are planned to operate, this line will not contribute to the reduction of freight transport time on the Middle Corridor.

3. Other projects on the Kars-Edirne transit route are designed for mixed traffic

The line connecting Sivas to Kars will be upgraded to $200 \mathrm{~km} / \mathrm{h}$ speed for mixed trafficpassenger and freight (UAB, 2019). Therefore, to extend the freight line to Ankara, it is logical to use the Ankara-Sivas HSR line for cargo transport as well.

The other important project on the transit route between Europe and China is the Halkal1Kapıkule railway project, launched in October 2019 to modernize the 229-km railway connection between Halkalı (Istanbul) and Kapıkule (the Bulgarian border). This project has a total value of EUR 1 billion, of which the EU provided Turkey a 275 million grant. The EU funding is part of the investment portfolio in Turkey financed through the Instrument for Pre-Accession Assistance (IPA) funds for the period 2014-2020. The double-track electrified line will have $200 \mathrm{~km} / \mathrm{h}$ design speed and will be equipped with signaling systems that are compatible with EU standards (ERTMS/ETCS Level 1) (Railwaypro, 2019).

4. Rail transport is suitable for the transport of high-value and e-commerce goods in Eurasian trade

The choice of rail instead of maritime or road shortens the transport time between Europe and China. Therefore, more high-value and capital-intensive products can be transported by intercontinental rail. Moreover, as a result of developments in logistics, less cargo than a full container load (LCL-Less than Container Loads) is now possible on Eurasian rail routes (Rastogi and Arvis, 2014), so shipments not large enough to fill a whole container be transported. This development creates a competitive advantage for rail freight. Transport of e-commerce products has great potential for the Eurasian container transport market, and the railway will play an important role in this market by filling a market niche with minimum environmental impact.

\section{Contribute to sustainable Eurasian transport}

The sustainability of a transport system is measured by its effectiveness, efficiency, and environmental impacts (Jeon and Amekudzi, 2005). The development of HSR freight transport may create great economic, social, and environmental benefits for society by reducing the number of trucks on roads, minimizing carbon dioxide emissions, and attracting new enterprises to HSR freight.

\section{Data and Methodology}

To find out if the market potential of Ankara-Sivas HSR (currently under construction) is enough to justify dedicated passenger use, and if there will be spare capacity for freight operations, we applied a simplified "gravitation approach" to the Ankara-Sivas HSR line to determine the "absolute traffic demand potential" (ATDP). ATDP only reflects the geographical and demographic conditions in the region, it does not consider the effect 
of the economic environment (GDP per capita value of a country and the time horizon in consideration) and the corresponding mobility level of the country. This approach was adapted from UNECE's Trans-European Railway High-Speed Master Plan Study-Phase 1 (2017). The absolute traffic demand potential shows the total potential of passenger traffic between two links, covering all modes in the considered route.

The formula of ATDP is as follows:

$P_{i-k}=a \cdot U_{i} \cdot U k / D_{i-k}{ }^{\mathrm{f}}$.

$\mathrm{P}_{\mathrm{i}-\mathrm{k}}$ number of travellers (e.g. per day)

a coefficient depending on several parameters, in particular GDP per capita (To compare links, as foreseen in the context of this study, this factor may be set $\mathrm{a}=1$, to obtain relative results $\mathrm{Pi}-\mathrm{k}$, not absolute figures.)

$\mathrm{U}_{\mathrm{i}}$ number of inhabitants of city $\mathrm{i}$

$\mathrm{U}_{\mathrm{k}}$ number of inhabitants of city $\mathrm{k}$ (It is better to use inhabitants of entire agglomerations, but these data are not generally available.)

$D_{i-k}$ distance of the urban agglomerations $U_{i}$ and $U_{k}$

$\mathrm{f}$ exponent describing the abating of the mutual attractiveness of the agglomerations dependening on distance ( $\mathrm{f}=1.7$ is used in all calculations).

The cities are listed with their numbers of inhabitants (in millions, e.g. Ankara 4,78 means 4.78 million inhabitants) and the links with their beeline lengths (in hundred kilometres, e.g. Ankara-Sivas 3,41 means $341 \mathrm{~km}$ ). In the first column and in the first row of the first section of Table 1 , the names of the cities Ui- $\nu$, respectively Uk- $\mu$; in the field where the second row and the second column cross, the beeline distance between Ui and Uk is listed. The second part of Table 1 for Ankara-Sivas has been completed with the individual results of applying the "gravitation formula," by multiplying together the numbers of inhabitants of the relative cities (see left columns and upper rows of the Table) and dividing each of the products by their mutual distance (see second columns from the left and second rows from above in the matrices of Table 1) to the power of 1.7. 
Table 1. Absolute traffic demand potential (ATDP) of Ankara-Sivas HSR line

\begin{tabular}{|c|c|c|c|c|c|c|c|c|c|c|c|c|}
\hline & & 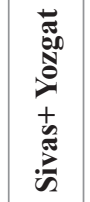 & 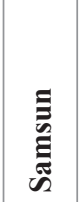 & $\underset{\mathrm{E}}{\mathrm{E}}$ & 立 & 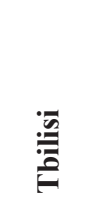 & $\frac{\bar{E}}{\tilde{\mathscr{n}}}$ & 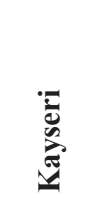 & 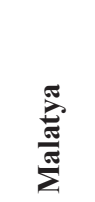 & 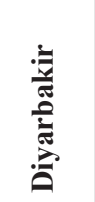 & $\stackrel{\Xi}{\tilde{\nu}}$ & 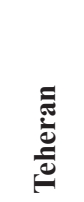 \\
\hline & & 0,49 & 0,61 & 0,35 & 0,12 & 1,17 & 2,14 & 1,06 & 0,35 & 0,93 & 0,35 & 8,15 \\
\hline \multicolumn{13}{|l|}{ Ankara+ } \\
\hline Kirikkale & 4,78 & 3,41 & 1,53 & 7,39 & 9,10 & 11,03 & 15,45 & 2,56 & 5,35 & 7,21 & 8,96 & 16,73 \\
\hline Eskisehir & 0,69 & 5,47 & 5,35 & 9,45 & 11,16 & 13,08 & 17,51 & 4,62 & 6,92 & 8,66 & 11,02 & 18,79 \\
\hline Adapazarı & 0,27 & 6,52 & 6,40 & 10,50 & 12,21 & 14,14 & 18,56 & 5,67 & 8,47 & 9,01 & 12,07 & 19,84 \\
\hline Istanbul & 14,66 & 7,77 & 7,65 & 11,75 & 13,46 & 15,39 & 19,81 & 6,92 & 9,72 & 10,23 & 13,32 & 21,09 \\
\hline Edirne & 0,15 & 9,90 & 9,78 & 13,88 & 15,59 & 17,52 & 21,94 & 9,05 & 11,85 & 12,39 & 15,45 & 23,22 \\
\hline Sofia & 1,21 & 12,83 & 12,71 & 16,81 & 18,52 & 20,45 & 24,87 & 11,98 & 14,78 & 16,63 & 18,38 & 26,15 \\
\hline Bucharest & 1,88 & 13,31 & 13,19 & 17,29 & 19,00 & 20,93 & 25,35 & 12,46 & 15,26 & 17,11 & 18,86 & 26,63 \\
\hline Belgrade & 1,35 & 16,18 & 16,06 & 20,16 & 21,87 & 23,80 & 28,22 & 15,33 & 18,13 & 19,98 & 21,73 & 29,50 \\
\hline Kutahya & 0,20 & 6,04 & 5,92 & 10,02 & 11,73 & 13,66 & 18,08 & 5,19 & 7,28 & 9,05 & 11,59 & 19,36 \\
\hline Balikesir & 1,19 & 7,82 & 7,70 & 11,80 & 13,51 & 15,44 & 19,86 & 6,97 & 9,12 & 14,08 & 13,37 & 21,14 \\
\hline Manisa & 0,28 & 9,06 & 8,94 & 13,04 & 14,75 & 16,68 & 21,10 & 8,21 & 9,47 & 11,19 & 14,61 & 22,38 \\
\hline Izmir & 4,11 & 9,35 & 9,23 & 13,33 & 15,04 & 16,97 & 21,39 & 7,28 & 9,74 & 11,44 & 14,90 & 22,67 \\
\hline Afyon & 0,21 & 6,99 & 6,87 & 10,97 & 12,68 & 14,61 & 19,03 & 6,14 & 6,77 & 8,50 & 12,54 & 20,31 \\
\hline Denizli & 1,00 & 8,06 & 7,94 & 12,04 & 13,75 & 15,68 & 20,10 & 7,21 & 8,10 & 9,78 & 13,61 & 21,38 \\
\hline Konya & 1,22 & 5,69 & 5,57 & 9,67 & 11,38 & 13,31 & 17,73 & 4,84 & 5,13 & 6,80 & 11,24 & 19,01 \\
\hline Antalya & 2,22 & 7,62 & 7,50 & 11,60 & 13,31 & 15,24 & 19,66 & 4,68 & 6,89 & 8,47 & 11,24 & 20,94 \\
\hline Mersin & 0,96 & 8,67 & 8,55 & 12,65 & 8,46 & 16,26 & 20,68 & 2,28 & 3,67 & 5,08 & 13,17 & 22,09 \\
\hline Adana & 1,72 & 3,40 & 4,85 & 6,10 & 7,84 & 16,00 & 20,42 & 1,94 & 3,03 & 4,43 & 7,27 & 21,83 \\
\hline Gaziantep & 1,56 & 3,00 & 4,85 & 4,63 & 6,34 & 8,23 & 11,44 & 2,50 & 1,65 & 2,68 & 5,51 & 16,02 \\
\hline \multicolumn{13}{|l|}{ Ankara+ } \\
\hline Kirikkale & & 0,291 & 1,415 & 0,056 & 0,013 & 0,094 & 0,097 & 1,025 & 0,097 & 0,155 & 0,040 & 0,324 \\
\hline Eskişehir & & 0,019 & 0,024 & 0,005 & 0,001 & 0,010 & 0,011 & 0,054 & 0,009 & 0,016 & 0,004 & 0,038 \\
\hline Adapazarı & & 0,005 & 0,007 & 0,002 & 0,000 & 0,003 & 0,004 & 0,015 & 0,003 & 0,006 & 0,001 & 0,014 \\
\hline Istanbul & & 0,220 & 0,281 & 0,078 & 0,021 & 0,164 & 0,196 & 0,580 & 0,107 & 0,262 & 0,063 & 0,670 \\
\hline Edirne & & 0,001 & 0,002 & 0,001 & 0,000 & 0,001 & 0,002 & 0,004 & 0,001 & 0,002 & 0,001 & 0,006 \\
\hline Sofia & & 0,008 & 0,010 & 0,003 & 0,001 & 0,008 & 0,011 & 0,019 & 0,004 & 0,009 & 0,003 & 0,038 \\
\hline Bucharest & & 0,011 & 0,014 & 0,005 & 0,002 & 0,013 & 0,017 & 0,027 & 0,006 & 0,014 & 0,004 & 0,058 \\
\hline Belgrade & & 0,006 & 0,007 & 0,003 & 0,001 & 0,007 & 0,010 & 0,014 & 0,003 & 0,008 & 0,003 & 0,035 \\
\hline Kutahya & & 0,005 & 0,006 & 0,001 & 0,000 & 0,003 & 0,003 & 0,013 & 0,002 & 0,004 & 0,001 & 0,011 \\
\hline Balikesir & & 0,018 & 0,023 & 0,006 & 0,002 & 0,013 & 0,016 & 0,046 & 0,010 & 0,012 & 0,005 & 0,054 \\
\hline Manisa & & 0,003 & 0,052 & 0,042 & 0,039 & 0,036 & 0,031 & 0,054 & 0,056 & 0,065 & 0,039 & 0,030 \\
\hline Izmir & & 0,045 & 0,057 & 0,018 & 0,005 & 0,039 & 0,048 & 0,149 & 0,030 & 0,061 & 0,015 & 0,166 \\
\hline Afyon & & 0,004 & 0,005 & 0,001 & 0,000 & 0,003 & 0,003 & 0,010 & 0,003 & 0,005 & 0,001 & 0,010 \\
\hline Denizli & & 0,014 & 0,018 & 0,005 & 0,001 & 0,011 & 0,013 & 0,037 & 0,010 & 0,019 & 0,004 & 0,045 \\
\hline Konya & & 0,031 & 0,040 & 0,009 & 0,002 & 0,018 & 0,020 & 0,089 & 0,026 & 0,044 & 0,007 & 0,067 \\
\hline Antalya & & 0,034 & 0,044 & 0,012 & 0,003 & 0,025 & 0,030 & 0,171 & 0,029 & 0,055 & 0,013 & 0,103 \\
\hline ATDP & 9,338 & & & & & & & & & & & \\
\hline
\end{tabular}

The sum of all the inner fields of the second part of Table 1 is the ATDP value of the Ankara-Sivas HSR line, which is 9,338. This value only represents sizes and distances between cities. In order to also include the influence of growing traffic demand, "weighted traffic demand potential" (WTDP) of Ankara-Sivas HSR for the years 2030 and 2050 is calculated by using the GDP per capita estimations of the Vienna Institute for International Economic Studies (WIIW) for 2030 and 2050. As shown in Table 2, the ATDP of the Ankara-Sivas HSR line is multiplied by the relevant GDP per capita quotient (GDP of Turkey/EU average GDP per capita in 2016) to find out the WTDP figure of this line. 
Table 2. Weighted traffic demand potential (WTDP) of Ankara-Sivas HSR line

\begin{tabular}{|c|c|c|c|c|c|c|c|c|c|}
\hline & \multicolumn{5}{|c|}{$\begin{array}{c}\text { GDP-Ratio: GDP per capita (year)/ EU } \\
\text { average } 2016\end{array}$} & \multicolumn{4}{|c|}{ WTDP $=\mathbf{A T D P} *$ GDP-Ratio } \\
\hline & ATDP & 2030 & $\begin{array}{l}2050 \\
\text { Low }\end{array}$ & $\begin{array}{c}2050 \\
\text { Medium }\end{array}$ & $\begin{array}{l}2050 \\
\text { High }\end{array}$ & 2030 & $\begin{array}{l}2050 \\
\text { Low }\end{array}$ & $\begin{array}{c}2050 \\
\text { Medium }\end{array}$ & $\begin{array}{l}2050 \\
\text { High }\end{array}$ \\
\hline Ankara-Sivas & 9,338 & 0,86 & 0,86 & 1,03 & 1,20 & 8,03 & 8,03 & 9,62 & 11,21 \\
\hline
\end{tabular}

The resulting WTDP values for the lower scenario ("L") for 2050 and those for 2030 are equal with the assumption that from 2030 to 2050, no further growth will take place. This WTDP approach allows a simple but reasonable estimation to find out whether the future traffic demand is appropriate only for dedicated or mixed traffic. For comparison, the WTDP figures of some other HSR links are given in Table 3.

Table 3 . Weighted traffic demand potential (WTDP) of some other HSR lines

\begin{tabular}{|c|c|c|c|c|c|c|c|c|c|}
\hline & \multirow[b]{2}{*}{ ATDP } & \multicolumn{4}{|c|}{$\begin{array}{l}\text { GDP-Ratio: GDP per capita (year)/ } \\
\text { EU average } 2016\end{array}$} & \multicolumn{4}{|c|}{ WTDP $=$ ATDP $*$ GDP-Ratio } \\
\hline & & 2030 & $\begin{array}{l}2050 \\
\text { Low }\end{array}$ & $\begin{array}{l}2050 \\
\text { Medium }\end{array}$ & $\begin{array}{l}2050 \\
\text { High }\end{array}$ & 2030 & $\begin{array}{l}2050 \\
\text { Low }\end{array}$ & $\begin{array}{l}2050 \\
\text { Medium }\end{array}$ & $\begin{array}{l}2050 \\
\text { High }\end{array}$ \\
\hline $\begin{array}{l}\text { Edirne - } \\
\text { Istanbul }\end{array}$ & 10.105 & 0,86 & 0,86 & 1,03 & 1,20 & 8,69 & 8,69 & 10,41 & 12,13 \\
\hline $\begin{array}{l}\text { Eskisehir } \\
\text {-Istanbul }\end{array}$ & 19.336 & 0,86 & 0,86 & 1,03 & 1,20 & 16,63 & 16,63 & 19,92 & 23,20 \\
\hline $\begin{array}{l}\text { Polatli- } \\
\text { Eskisehir }\end{array}$ & 17.701 & 0,86 & 0,86 & 1,03 & 1,20 & 15,22 & 15,22 & 18,23 & 21,24 \\
\hline $\begin{array}{l}\text { Cologne- } \\
\text { Frankfurt }\end{array}$ & 12.247 & 1,54 & 1,54 & 1,74 & 1,94 & 18,86 & 18,86 & 21,31 & 23,76 \\
\hline $\begin{array}{l}\text { Paris - } \\
\text { Lyon }\end{array}$ & 11.256 & 1,39 & 1,39 & 1,53 & 1,67 & 15,65 & 15,65 & 17,22 & 18,80 \\
\hline
\end{tabular}

Table 3 shows that Paris-Lyon, Cologne-Frankfurt, and Polatli-Eskisehir-Istanbul HSR lines have a high enough level of traffic demand to justify the investment due to the significant number of large cities (Istanbul in particular) located at relatively close distances, and also economic growth. The WTDP of Ankara-Sivas is quite lower than other examples and high-speed on this line might not be justified by passenger traffic alone. However, prior to decision-making, a more in-depth investigation of traffic demand might be needed since the resulting WTDP figures only indicate the traffic demand in a certain link, covering all modes of transport, due to geographical conditions and population. The real exhaustion of this potential for rail depends on its competitiveness against other modes in terms of travel times and prices, as well as soft factors like the service quality of rail, etc.

\section{Conclusions}

Turkey has a key location along the Eurasian Middle Corridor between Europe and China, which may result in fast-growing freight transport in the future, resulting in the need for new capacities for freight. This may mean that HSR projects become viable when carrying passengers and freight together. The development of a HSR line requires 
large construction and operating costs. Thus, the economic rationale for the new HSR infrastructure largely depends on the expected volume of demand. Turkey is investing a lot in HSR projects. In this study, we investigated whether the market potential of the Ankara-Sivas HSR under construction is enough to justify passenger use only, and whether there will be any spare capacity for freight operations. We have chosen the Ankara-Sivas HSR line as a case because this line is an important section of the Eurasian transit corridor between Europe and Asia. Any improvement in the transit time will contribute much to the competitiveness of the Eurasian Middle Corridor. As a result of the analysis, we have found that the traffic potential on the Ankara-Sivas HSR line might not be justified by passenger traffic alone. There is a new opportunity for express freight trains using HSR. Railways can transport freight from China quicker, cheaper, and greener, despite the need for gauge changes and border crossings. The HSR can offer a fast, reliable, and convenient way to transport high-value, low-weight goods. The negative impact on the economy and environment highlights the importance of HSR as a good alternative for express freight transport. In this study, we applied a simplified "gravitation approach" to the Ankara-Sivas HSR link to determine the "absolute traffic demand potential" (ATDP) and "weighted traffic demand potential" (WTDP). This approach allows a simple but reasonable estimation to find out the future traffic demand. However, these methods cannot replace a more in-depth investigation of traffic demand prior to decision-making. Moreover, the technical and operational limitations of using the Ankara-Sivas HSR line for freight have not been studied. These may be the subject of further studies.

Peer-review: Externally peer-reviewed.

Conflict of Interest: The author has no conflict of interest to declare.

Grant Support: The author declared that this study has received no financial support.

Hakem Değerlendirmesi: Dış bağımsız.

Çıkar Çatışması: Yazar çıkar çatışması bildirmemiştir.

Finansal Destek: Yazar bu çalışma için finansal destek almadığını beyan etmiştir.

\section{References}

Albalate, D. \& Bel, G. (2012).The Economics and Politics of High-Speed Rail : Lessons From Experiences Abroad, Lanham, Md : Lexington Books.

Amos, P., Bullock, R. \& Sondhi J. (2010). High -Speed Rail: The Fast Track to Economic Development? The World Bank. July.

Calabrese, J. (2019). Setting the Middle Corridor on track. Accessed from https://www.mei.edu/publications/ setting-middle-corridor-track on March 18,2020.

De Rus, G. (ed.), Barrón, I., Campos, J., Gagnepain, P., Nash, C., Ulied, A. \& Vickerman, R. (2009). Economic Analysis of High-Speed Rail in Europe. BBVA Foundation, Bilbao.

Ertem M.A.\& Özcan, M.K. (2016): Freight transportation using high-speed train systems, Transportation Letters. http://dx.doi.org/10.1080/19427867.2015.1122395

European Court of Auditors.(2018). Accessed from https://op.europa.eu/webpub/eca/special-reports/highspeed-rail-19-2018/en/ on 03 May 2020. 
Gao, G., Jiang, C. \& Larson, P.D. (2017). Express Freight Transportation by High-Speed Rail: The Case of China, Proceedings of the 52nd Annual Conference Canadian Transportation Research Forum Winnipeg, Manitoba, May 28-31.

Jeon, C. M. \& Amekudzi, A. (2005). Addressing Sustainability in Transportation Systems: Definitions, Indicators, and Metrics, Journal of Infrastructure Systems, 11, 31-50.

Middle Corridor (2020). Accessed from https://middlecorridor.com/en/route on January 16, 2020.

Nikkei Asian Review. (2019). Accessed from https://asia.nikkei.com/Spotlight/Belt-and-Road/Chinesefreight-train-skirts-Russia-on-new-route-into-Europe on 09 December 09, 2019.

Pazour, J.A., Meller, R.D., \& Pohl, L. M. (2010). A model to design a national high-speed rail network for freight distribution Transportation Research Part A: Policy and Practice, 44 (3), 119-135.

Railway Technology. (2018). Moscow-Kazan High-Speed Rail Line - Railway Technology. [online] Accessed from http://www.railway-technology. projects/moscow- kazan-high-speed-rail-line on10 May 2020.

Railwaypro, (2019). Accessed from https://www.railwaypro.com/wp/halkali-kapikule-railway-projectlaunched/october on 01 May, 2020.

Rastogi, C.\& Arvis. J.F. (2014). The Eurasian Connection Supply-Chain Efficiency along the Modern Silk Route through Central Asia. World Bank, Washington.

Troche, G. (2005). High-Speed Rail Freight, Report No: 0512; Stockholm, KTH Railway Group.

UAB.(2019). Ulaşan ve Erişen Türkiye. Ulaştırma ve Altyapı Bakanlığı(Ministry of Transport and Infrastructure of Turkey)Kasım, Ankara

UAB.(2020). Accessed from https://www.uab.gov.tr/uploads/pages/butce-sunumlari/2020-butce-sunumu. pdf on 12 May 2020.

UIC. (2020a) Accessed from https:/uic.org/passenger/highspeed/article/high-speed-rail-history on 18 April 2020.

UIC. (2020b). High-Speed Database and Maps, Accessed from https://uic.org/passenger/highspeed/article/ high-speed-database-maps on 12 March 2020.

UNECE (2017). TER master plan study Trans-European Railway High-Speed Master Plan Study Phase 1.

Vienna Institute for International Economic Studies (2017). "Wiener Institut für internationale Wirtschaftsvergleiche" - WIIW, March.

Watson, I, Ali, A \& Bayyati, A. (2018). An Investigation into the Benefits and Constraints of Shifting Freight Traffic onto High-Speed Railways. COMPRAIL 2018, Wessex Institute of Technology (WIT). Lisbon, Portugal 02 - 04 July.

Watson, I, Ali, A \& Bayyati, A. (2019). Freight Transport Using High-Speed Railways, International Journal of Transport Development and Integration, 3(2), $103-116$. 
